\title{
STATE, INSTITUTIONAL, AND SYMBOLIC VIOLENCE AGAINST WOMEN: THE STRUGGLE SINCE THE «ARAB SPRING» AND THE CONTRIBUTION OF ARAB WOMEN CARTOONISTS
}

\author{
LILIA LABIDI \\ University of Tunis
}

Recibido: $12 / 08 / 2015$

Aceptado: 18/10/2015

\section{Resumen}

Este artículo analiza los cambios que se han producido en Túnez en el debate público sobre la violencia contra las mujeres, comparando la situación que había antes y después de la «Primavera árabe» en diciembre de 2010. Da las claves de los hechos posteriores a diciembre de 2010 y explora cómo estos influyeron en el debate público. El artículo analiza diversas viñetas de cuatro mujeres dedicadas al humor gráfico, una de Túnez y las otras tres de otros países árabes, que están dedicadas a denunciar la violencia contra las mujeres. Argumenta que el humor puede ayudar a denunciar dicha violencia, y que los movimientos de mujeres en el mundo árabe deben hacer más esfuerzos para incluir a las mujeres marginadas en sus luchas.

Palabras clave: mujer, violencia, árabe, Túnez,

\begin{abstract}
This paper traces changes in Tunisian public discussion of violence against women, comparing the situation before and after the start of the «Arab spring» in December 2010. It highlights key events following December 2010 and explores how these influenced public discussion. The paper concludes by looking at several cartoons from four women cartoonists, one from Tunisia, three from other countries in the Arab world, that address issues of violence against women. It suggests that humor may help denounce violence against women, and argues that the women's movements in the Arab world must do more to include marginalized women in their struggles.
\end{abstract}

Keywords: Women, Violence, Arab, Tunisia, Cartoon 



\section{Context}

Among the changes in Tunisia occurring since the outbreak of the «Arab spring,» we see a public debate emerging on violence against women and a return of women's forms of expression like humor (fukaha) that had been neglected during the colonial period from 1881 to 1956 and under the post-independence authoritarian regimes from 1956 to 2011. Public discussion of violence against women had been taboo because this was seen as calling into question women's rights that were guaranteed since 1956 under the Personal Status Code that gave women many rights, such as forbidding polygamy; requiring that divorce be via judicial procedure, that men and women be paid equally for equal work, that women have the right to vote and to be elected to public office and the right to have custody of her children in case of divorce; requiring the mother's approval for the marriage of a daughter under 15 years of age; giving Tunisian nationality to children of a non-Tunisian father, etc.

Since 14 January 2011, the day that Ben Ali fled Tunisia, the lifting of censorship allowed the media between 2011 and 2014 to report cases of violence against women, such as assassinations, collective rapes of adolescents and of adult women in the presence of their children, and even of aged women. This was happening in a context where Tunisia, which had had only a few women's associations before the revolution, saw an explosion in the number of such associations, and their forms of activism also evolved. Formerly, independent women's associations had been tightly controlled by the authoritarian regimes, but after January 2014 they multiplied their campaigns opposing violence against women. A coalition of Tunisian women, made up of 15 associations, organized an activity that highlighted the economic violence that women suffered. Another association, Aswat Nissa (Women's Voices), initiated an action at Bab Souika(a working-class area in the Tunis medina) and at university and secondary schools, using leaflets, posters, and banners. They enlisted the participation of men, religious leaders, preachers, and journalists, and set up a venue where women could come to give voice to their problems. The Tunisian Association of Democratic Women (ATFD) carried out a campaign 
to raise awareness of violence against women and to support promulgation of a law, in 2014, opposing violence against women.

The use of new technologies to denounce violence against women also increased. Several videos with the theme of violence against women were put on Youtube, sometimes produced with the support of UN agencies, the European Union, or in collaboration with other organizations. The association Beity, formed after 2011, mounted a campaign opposing violence and discrimination against women, criticizing a very popular television program, Andi Manqullik(I have something to tell you), produced by a private TV channel, al-Hiwar Et-Tounsi (Tunisian Dialogue). On the program women victims of violence are invited by their husbands who admit having been violent with their wives, ask to be pardoned, and propose living together again. When the wives refuse, despite the encouragement of Alaa Chabbi, the program's host, some of the men admit that they wanted to try to live with their wives again before meeting the judge, so that they could avoid paying the alimony that the judge would require. Beity's video critique of the program, which ends with a statement that violence is punished by law and that it is doubly punished when it occurs within a couple, was very widely viewed online ${ }^{1}$.

This follows years when the discussion of violence against women was marked by competition between national and independent women's organizations, particularly under the Ben Ali regime when the UNFT, the government-controlled national women's organization, attempted to control the discourse. Now, after the revolution, even the General Union of Tunisian Workers (UGTT), a labor union which is a powerful national organization, has showed an interest in joining the struggle opposing violence against women, carrying out a study showing that $50 \%$ of Tunisian women were victims of one or more of four forms of violence - physical, psychological, sexual, economic (in decreasing order of frequency) - and called for the promulagtion of a law penalizing violence against women ${ }^{2}$. The Ministry of Women's Affairs publicized a study carried out in 2010 by the National Office of the Family and Population on violence against women and since 2014 has been preparing a law opposing violence against women. In 2015, the ministry announced that this would be submitted to the Assembly of the Representatives of the People (ARP) at the end that year. We have also seen the emergence of women cartoonists and their involvement in the struggle opposing violence against women, a subject I will be dealing with in section II.

1. The video clip of the association Beity was seen 16,677 times.

2. Unsigned article. «Après le 14 janvier, la violence contre la femme en Tunisie est en hausse». Tunisie Focus 3 July 2015. 
However, in the majority of instances, while domestic violence was a focus of concern, state violence, symbolic violence and institutional violence were not addressed systematically. We take from Max Weber the concept of state violence, which exists when the state no longer has a monopoly on legitimate violence, that is, violence carried out with the consent of citizens. Symbolic violence, according to Pierre Bourdieu, occurs when power «extracts submissions which are not perceived as such, basing itself on 'collective expectations,' beliefs that are socially inculcated», and this notion allows us to perceive and understand other forms of violence (Bourdieu 188). The third of these forms of violence against women, the institutional violence that Xavier Albó and Raul Barrios speak of, refers to all «moral or physical pressure, exerted directly or indirectly through institutions or institutional apparatus on human beings put voluntarily or involuntarily into social groups tied to this apparatus»(17). These concepts are useful to us in understanding the impact of various forms of violence in the context of colonialism and the post-independence dictatorial regimes in Tunisia.

Among the authors who have written about people living under dictatorships, Lia Ricon and Janine Puget, who worked on the consequences of trauma in such contexts, have raised a number of problems. Authoritarian discourse, writes Lia Ricon, influences personality construction and encourages the appearance of serious pathologies. She considers authoritarianism, as in the case of military junta commanders, to be a significant distortion of authority of a sort that structures the psyche $(73,84)$. As for Janine Puget, she notes how the violence of the state produces a rupture in social exchange, isolation and silence. Consequently, the subjects' need to create defensive barriers is in direct relation to the denial of terror. She refers to the difficulty psychoanalysts had in practicing their profession in Argentina during the period of unrest caused by state terrorism because everyone, without exception, suffered from it. And she suggests that psychoanalysts must admit this, in order to maintain their capacity to think and not succumb to this kind of phenomenon $(39,18)$. And Maren UlriksenVignar and René Kaës reflect on the means subjects have to reconstitute themselves, with Ulriksen Vignar suggesting that restoring memory can give meaning to suffering experienced during a limit-experience $(123,128,130)$, and René Kaës emphasizing the danger faced when the state refuses to recognize historical memory, thus encouraging the emergence of murderous utopianism (202).

We will treat here, in the first section, a number of cases of violence experienced by women in Tunisia and in the wider Maghreb from the 1950s until today, using a variety of documents such as life stories collected by the author, 
observations, press articles, as well as research carried out on this subject in the region, in an effort to contribute to the social memory of women victims of violence during colonialism, under the post-independence authoritarian regimes, and following the «Arab spring,» so that the victims and future generations do not repeat the same errors, don't have recourse to masochistic submission, and don't renounce universal values or adopt the values of the people in power (Puget 18). In the second section we will discuss the work of women cartoonists from Tunisia, placing them in the regional context where women cartoonists in countries such as Egypt, Bahrain and Saudi Arabia, are using humor to denounce violence against women and show us what remains of the traumatism.

\section{Violence against women}

In this section we will bring forward cases of state, symbolic and/or institutional violence against women from the 1950s to today.

\subsection{State violence}

The theme of violence, occurring frequently in the work of Maghreb feminists of the 1970s, testifies to an imaginary marked by political violence, where women were victims of such episodes during the colonial period as well as by the armies and police of the newly independent Arab states. Three examples follow.

1.1.1. During the colonial period the rapes of Hafsia ElAbrougui and Djamila Boupacha during the 1950s, among many others, marked the history of the region and of France. Hafsia ElAbrougui, a Tunisian adolescent, was raped at Tajarouine in the presence of her crying grandmother who was unable to stop the French soldiers from committing their crime. At the same time in another farm, her male cousin was also raped in front of the men of the family, and they too were unable to prevent the crime (Labidi 2009, 37-38). In Algeria Djamila Boupacha, accused of having placed live artillery in the Algiers university café, was raped during interrogation by French soldiers who used a bottle to violate her (Halimi). Djamila Boupacha wrote a letter to her lawyer, Giselle Halimi, confiding that, out of modesty, she would not be able to speak about her rape during the hearings because her father would be present.

The mobilization of lawyers, intellectuals, filmmakers, etc. in the case of Djamila Boupacha, led to denunciations of the rape of women. Giselle Halimi, a French-Tunisian lawyer did much to raise consciousness regarding Boupacha's case, including among the elite, publishing Djamila Boupacha in 1962, 
with a preface by Simone de Beauvoir. The life stories of women activists raped by the French colonial army in Tunisia were collected and published in Tunisia in the 2000s (Labidi 2009), as were others in the other Maghreb countries, without this leading to any public recognition of these women's memories such as exists in Vietnam where museums have been devoted to celebrate women militants.

While women's organizations in Tunisia and the Maghreb often looked to the definitions of violence used by UN agencies to get their own governments to adopt laws protecting women, it was only with the «Arab spring» that rape was recognized to be a «terrorist crime,» in 2015. Yet in Tunisia very few women have submitted their cases to the Authority for Truth and Dignity (L'Instance Vérité et Dignité (IVD), Hay'at al-Haqiqat wa al-Karama) formed as a result of demands for transparency and accountability, in the framework of the transitional justice of the «Arab spring.» 1,626 cases were presented by women, of which 400 by former prisoners, only two of the total referred to rape, among the first 13,278 cases submitted to the IVD. This small number was explained by Ibtihel Abdelatif, President of the IVD's Women's Committee, by the women's distance from Tunis, the cost of transportation, the need to have the husband's authorization, and that women victims of violence do not see themselves as victims even when they have been objects of degrading insults, sexual touching, forced nudity up to and including rape (sometimes accomplished with objects).

1.1.2. Sexual violence has also been used as a political weapon in a number of countries in the region. Starting in the 1970s leftist and Islamist activists were being tortured in Tunisian prisons, and women were among these activists. Kuwaiti women were victims of rapes carried out by the Iraqi army during the 1990 invasion of Kuwait by Iraq. In Europe in 1992, in the context of ethnic cleansing, Muslim women in Bosnia-Herzegovinia were mass raped by Serbian extremists (Egalité Maintenant). And Iraqi women were raped by US soldiers following their invasion of Iraq in 2003. The UN Security Council finally recognized rape as a crime and the tribunal set up to investigate crimes committed in the former Yugoslavia determined, in 1993, that rape constituted a crime against humanity (Programme de Communication...). Later, the World Health Organization, in 2002, defined collective violence as political, religious, racist violence, as state violence and violence in the context of conflicts (war, massacres, terrorism, torture, rape, genocide, deportation), and also as economic and social violence. In each of these categories, the violence may be verbal, physical, sexual, and/or related to negligence and undue 
hardships. To which can be added symbolic violence related to discrimination and/or domination (be it racial, sexual, etc.) treated by Bourdieu and Muriel Salmona.

1.1.3. On the level of the Maghreb, sexual violence has also been carried out by representatives of institutions that were supposed to protect women and young girls. In 1992, Morocco was shaken by the discovery of some 100 video cassettes showing more than 500 women engaged in forced sexual activities with political and media figures, both Moroccan and foreign, organized by police chief. Civil society and women's organizations brought a civil case before the courts to defend women's rights. Although some victims conquered their fear and initiated a court case, it was only one year later that the case was heard, and the police chief received the death sentence and was executed.

In Tunisia, in September 2012, after several weeks of mobilizing against the adoption of the term «complementarity» in the projected new constitution, people were shocked to hear of the repeated rape of Meriem, aged 27 and with a degree in finance, by two on-duty policemen, as a third forced Meriem's fiancee to hand over money. With this, Tunisians discovered the dark side of those who were supposed to protect them (Ben Mohamed). The justice system under the Troika coalition(composed of the Nahdha party - the strongest of the three - and two other left-leaning parties, al-Mu'tmar min ajl al-Jumhuriyyah (Congress for the Republic) and at-Takattul ad-Dimuqrati min ajl il-Amal wal-Hurriyyat (Democratic Forum for Labor and Freedom) appeared to be attempting to tarnish the victim, suggesting her responsibility for the crime. The lawyers for the policemen emphasized the fact that the young woman was not a virgin, claimed she had regular sexual activity, and so on. Disappointed by the lack of support for women's rights in such circumstances, and with Meriem, since her rape, suffering from depression and post-traumatic stress, women's organizations brought a civil case to defend the victim's rights.

Then, when several months later, the media publicized the case of a three year-old girl who had been a victim of sexual touching by the caretaker of a nursery in the northern suburbs of Tunis in March 2013, emotions reached a climax and many elements in society became active ${ }^{3}$. A motion made at the

3. D.I. for TAP (Tunis Afrique Presse). Since 14 January 2011, the number of associations increased from 10,932(2011) to 17,627 in October 2014. Tunis accounts for $24.47 \%$ of associations, Sfax comes in second position, then Nabeul. The regions with the fewest associations are Tozeur and Zaghouan (see «Plus de la moitié des associations actives en Tunisie ne sont pas conformes à la loi» (30-10-2014), <http://directinfo. 
ANC challenging the Minister for Women's and Family Affairs, held by a CPR party member, for failing to protect young girls in institutions falling under the ministry's supervision, was defeated thanks to votes cast by the Nahdha party, the strongest party in the Troika.

While in both cases political alliances led to defeats for women's rights, the mobilization of women to protect the women's rights had some positive impact. After several postponements the two policemen were finally found guilty of Meriem's rape and were each sentenced to seven years in prison, raised to 15 years on appeal. And in the case of the three year-old girl, the nursery was closed and the caretaker put in prison. These two events revived the anger that had been provoked earlier by parliamentarian Souad Abderrahim's criticisms of single mothers in Tunisia immediately following her success in the October 2011 elections, when she contributed significantly to the success of the Nahdha party and where she did not defend these women's rights.

Rarely did the women victims of rape publish their own stories in the Maghreb, until Meriem Ben Mohamed (a pseudonym) published her testimony, in France in 2013, under the title, Coupable d'avoir été violée (Guilty of being raped). Nor did women political militants publish books when made-up photos and press articles defamed them, as in the cases of human rights activists Sihem Ben Sedrine and Radhia Nasraoui, etc. But we are now seeing women give their testimony increasingly on the web ${ }^{4}$.

Signs of the growing discussion of the violation of women's rights women can be seen in some films treating this subject. Among these we find Les sabots en or (Golden Horseshoes) (Nouri Bouzid, 1988) and La mémoire noire, témoignages contre l'oubli (Black memory, witnesses against forgetting) (Hichem Ben Ammar, 2013) - both films devoted to leftist opposition activists during the 1960s and 1970s. Among the filmmakers treating violence against women in politics, we see Youssef Chahine's 1958 film Djamila l'Algérienne, devoted to Djamila Bouhireb. In Tunisia we find a film directed by a woman, Les silences du Palais (Silences of the Palace) (Moufida Tlatli, 1994), which treats the trafficking of women and sexual violence by the Tunisian rulers. A film dealing with sexual violence against opposition activists of both sexes is Al-Siraa (Conflict) (Moncef Barbouch, Tunisia, 2013), produced 20 years after Tlatli's film and showing activist women, relatives, and spouses who lived through the repression for their political views during the dictatorship from

webmanagercenter.com/2014/10/30/plus-de-la-moitie-des-associations-activesen-tunisie-ne-sont-pas-conformes-a-la-loi/>, consulted on 14-07-2015)

4. See «Tunisie: Prisonniers politiques, violation de la loi par le gouvernement»<https:// www.youtube.com/watch?v=ScWLOEAJfCg>, consulted on 15-07-2015. 
1987 to 2011 (Moncef Barbouch, living and making films while living in Canada, returned to Tunisia to make this film). In 2013 Arbia Abassi and Marwan Trabelsi, together with the Association Tunisienne de Droit au Développement and with the collaboration of the United Nations, made Al-Mugharabun (The Stateless Ones), where activists of both sexes in the Tunisian cities of Gafsa, Jendouba and Nabeul, relate their stories ${ }^{5}$. Algerian and Moroccan films have also dealt with similar questions.

Finally, the impact of mobilization for the defense of the rights of women victims of violence, as in the cases of Meriam and the three year-old girl, was so significant that finally the ARP adopted, in July 2015, a law that criminalized sexual touching of a man or woman, with offenders facing 20 years in prison or, in cases where the victim was a minor, capital punishment; and the law recognized, for the first time, rape to be a terrorist crime.

\subsection{Institutional violence}

Here I will be discussing, first, the case of women in rural areas and the state's relationship to them (see Labidi 2012, where the author discusses how the state gave responsibility for providing rural women with professional training to the UNFT, the national women's organization with close ties to the government); and second, I will look at the entrance of women in parliament, as an example of women's participation in formal political institutions.

1.2.1. With regard to the state's relationship to women in rural areas, I will concentrate on the adoption of laws that, while aiming to promote the reduction of births, contributed to strengthening controls over women and over their bodies, by coercion.

Tunisia's development policy had, as a central element, birth control. In July 1961, Law N 61 was adopted, relating to anti-conception remedies and abrogating the French law on abortion and contraception. Then, the law of 1 July 1965 allowed abortion during the first three months and when the couple had at least five living children, as well as where the health of the mother was compromised by the pregnancy. This law was strengthened in September 1973 by extending the possibility of abortion to all women who requested it.

5. D.I. for TAP (Tunis Afrique Presse). «Documentaire 'Les Apatrides': Témoignages accablants d'anciennes victimes de la torture en Tunisie» (03-02-2015) (<www.directinfo. webmanagercenter.com>. consulted on 12-07-2015). The director of this documentary, Arbia Abassi, made two short films, Tentation and Donia and co-directed Et pourtant ils respirent with Marwan Trabelsi. 
Family allowances were provided only for the first four children (laws of 14 December 1960 and 65/46 of 31 December 1965) and, in 1988, for the first three children. In February 1968, the minimum age at marriage was again raised, to the age of 17 for women and 20 for men. Finally, a National Office of Family Planning and Population was established in March 1973, under the Ministry of Health, in order to promote the modern family that is responsible for procreation.

In order to increase the number of sterilizations, the caregivers, doctors, and midwives, were awarded bonuses to their salaries for performing these operations. In addition, an award known as the Bourguiba Prize ( $1^{\text {st }}$ prize 10,000 dinars, $2^{\text {nd }}$ prize 6,000 dinars, $3^{\text {rd }}$ prize 4,000 dinars) was established in 1974, aiming to reward the provinces that achieved the best results in family planning (decree 74-724 of 16 July 1974), amounts which would be redistributed among those who achieved the highest scores, in order to encourage competition among the regions. Also, women who agreed to have Fallopian tube operations received in return food products to the value of five dinars (over \$10 US then), a sign of the poverty of the population at that time; those who had a young child could keep the child with them in the hospital and would be driven back to their homes in an institutional car. In this atmosphere of benefits and competition, the views of the women and of their husbands counted for little in the decisions of the caregivers.

Table: Doctors' and midwives' opinions concerning the husband's consent to abortion (\%) (Sahli 237).

\begin{tabular}{|l|l|l|}
\hline The husband's consent: & Doctors & Midwives \\
\hline is necessary & 37 & 20 \\
\hline isn't necessary & 60 & 77 \\
\hline don't know & 3 & 3 \\
\hline Number & 34 doctors & 115 midwives \\
\hline
\end{tabular}

During the period 1964-1980 the medical establishment encouraged «the tying of Fallopian tubes» as a solution to development issues. In the two-year period 1974-1975, the family planning program accomplished as many Fallopian tube operations as had been accomplished in the previous ten years, 1964-1973. From 1974-1980, 62,624 Fallopian tube operations were carried out, or an average of 9,000 per year. And, in 1978, $7 \%$ of married women of reproductive age had Fallopian tube operations - 17\% who had Fallopian tube operations were under 29 years of age and 56.5\% were between 30-39-96.4\% 
among them had no remunerative activity and 90\% were illiterate and the husbands were mostly day workers.

By the 1990s demographers were noting that the population trajectories of the three countries, Tunisia, Morocco and Algeria, were converging, despite the different methods employed by each - I.U.D. and sterilization played a major role in the Tunisian case, whereas the pill dominated in Morocco and Algeria ${ }^{6}$. In Tunisia, fertility reached 2.2 in 1998; in Morocco and in Algeria, fertility was 3.1 in 1997, compared to above 7 in 1960 (Vallin and Ouadah-Bedidi 1).

The forced sterilization of women in rural areas was a form of political control in certain Tunisian regions, applied without any serious examination of the implications of these different methods on women, on their family members, on their communities, on the social tensions arising, or on the morality of these methods in situations where, besides, the rate of maternal mortality and illiteracy of women in rural areas remain very high up until today.

The rate of maternal mortality in the Center-West was 55.9 per thousand in 2008; 67 per thousand in the North-West; and 36.7 per thousand in the South-West (Ben Romdhane 31). One-third of these were caused by hemorrhages. Kasserine, which has a population of 432,000 had only 45 doctors, including both public and private sectors. The regional hospital in this province carries out 6,500 childbirths per year, with 3,650 requiring surgery (M.B.Z.). In addition, many women need to travel between 20 and $30 \mathrm{~km}$ in order to reach a health center. The provincial governor, in August 2015, had to requisition doctors from the private sector in order to provide for the population's health care. In an angry reaction, the private sector doctors protested, arguing that their professional organization had not been consulted. Tunisian doctors, whose receive their medical training for free, have state salaries paid to them as interns and in residencies, and specialist training abroad paid for by the state, have refused to work in these regions and also opposed creating medical schools there, which would train local professionals who would base themselves in the regions and would go a long way to resolving this social injustice.

Such a policy of forced sterilization and other coercive techniques reduce a discourse since 1956 that promotes the emancipation of women to mere rhetoric. Decrees, laws, and technology were put into place to counter what

6. Touati et al shows that the pill was used by $5.4 \%$ of the women in their sample, an IUD by $31.1 \%$, and tying the Fallopian tubes by $12.7 \%$. Among women of reproductive age, $16.5 \%$ (211 of 944) had one abortion and $9.6 \%$ (122 women) had two or more. 
technocrats considered the sexual disorder of rural populations in order to protect the modernization of the state. The «Arab spring» revolution broke out in just those regions where women had been forcibly sterilized and where youth - that is, the grandchildren of these women - demonstrated to demand «Freedom, work, and dignity» between December 2010 and January 2011.

1.2.2. Before the «Arab spring» women's struggles focused on the widespread view that women could not reconcile family, professional, and political aspects of their lives, which limited their access to decision-making positions, which they occupy even today in only very small numbers. The self-immolation of Mohamed Bouazizi, on 17 December 2010, led to a protest movement among women who saw reflected in his action their own economic, cultural, and political marginalization. In 2011, strengthened by their struggles for their rights, Tunisian women gained the right to have their identity photographs taken with the hijab, saw the passage of a national electoral law mandating political parity, and Tunisia lifted its reservations concerning the Convention for the Elimination of all forms of Discrimination Against Women(CEDAW). While the number of women members of the Tunisian parliament began to increase in the 1980s, it was only starting in the 2000s that these numbers jumped significantly. The elections of 2011 and 2014, while not ensuring that political parties selected women candidates for reasons free of cronyism and close social ties, the competition resulting from political pluralism had positive consequences for women, enabling women with a variety of perspectives to participate, for the first time in Tunisian political history, in the writing of the new constitution, and also enabling women outside parliament to act to influence its content in the direction of promoting women's rights.

These progressive steps are the result of policies of quotas for women and later, of parity, permitting women to enter parliament. Most of the women elected before 14 January 2011 were members of the parties in power - the Destourian Socialist Party (PSD) under Bourguiba and the Democratic Constitutional Rally(RCD) under Ben Ali - and were coopted by their allegiance to those in power, something experienced by independent women as a form of political violence. The demand for political parity began to be heard starting in 1989. After the October 2011 elections, parity and political pluralism enabled women from a variety of political parties to enter parliament. As well, the number of women in parliaments in the countries of the Maghreb progressed in 2011, whereas in Egypt there was a decline. And, for the first time, 30 women entered the Majliss al-Shura (Official consultative council) in Saudi Arabia, in January 2013. 
Table 2: Number of women in parliament in Arab countries (Inter-Parliamentary Union).

\begin{tabular}{|l|l|}
\hline Country & 2015 \\
\hline Tunisia & 68 of 217 \\
\hline Algeria & 146 of 462 \\
\hline Morocco & 67 of 395 \\
\hline Lebanon & 4 of 128 \\
\hline Egypt & $\begin{array}{l}2 \% \text { in } 2011, \text { compared to } 12.7 \% \text { in } \\
\text { the previous elections }\end{array}$ \\
\hline Jordan & 18 of 150 \\
\hline Libya & 30 or 33 of 188 \\
\hline Iraq & 87 of 328 \\
\hline Saudi Arabia & 30 of 151 \\
\hline Kuwait & 1 of 65 \\
\hline Bahrain & 3 of 40 \\
\hline Qatar & 0 of 35 \\
\hline Yemen & 0 of 300 \\
\hline
\end{tabular}

The feminist struggles in Tunisia opened the door to the election of women from the Nahdha party in 2011, enabling them to participate in the writing of the third Tunisian constitution. However, the proposal of Nahdha party women parliamentarians to use the term «complementarity» between the sexes in the constitution led to great controversy. Under the pressure of protests from women, civil society, and political parties the Tunisian Constitution adopted in January 2014 finally reflected a consensus among cultural and political forces in using the term «equality between the sexes», and guaranteeing women's rights and freedom of expression. In 2015, a press conference organized by 16 women's associations, both old and new ones, aimed to raise public awareness of the importance of gender parity in access to decision-making positions in the public sector ${ }^{7}$.

7. Unsigned article. «La parité d'accès aux postes de décision dans la fonction publique entre les hommes et les femmes, point en commun et de départ du mouvement féminin en Tunisie» (22-04-2015). < http://www.baya.tn/2015/04/22/la-parite-dacces-aux-postesde-decision-dans-la-fonction-publique-entre-les-hommes-et-les-femmes-pointen-commun-et-de-depart-du-mouvement-feminin-en-tunisie/ > 


\subsection{Symbolic violence}

In this section I will discuss two cases illustrating symbolic violence against women. The first deals with two articles appearing in the Tunisian press, showing the conflicted relations between the state and feminists; the second deals with the hijab and its use as a way to discriminate against women.

1.3.1. In the first case, the articles revealing the tensions between the state and feminists appeared in 2004 in the Tunisian press, from the pens of Nadia Omrane and Fatma Haddad-Chamakh. In order to see what is at stake, we need to situate the women's movement in Tunisia which, up until 2011, was dominated by two orientations: 1) the UNFT (The National Union of the Tunisian Woman) and later by the ATM (Tunisian Association of Mothers), both of which were close to the institutions of power and represented what we have called «state feminism»; 2) the ATFD (Tunisian Association of Democratic Women) and AFTURD (Association of Tunisian Women for Research on Development), two independent associations that were often in opposition to those in power.

Nadia Omrane, a journalist and essayist and speaking from the point of view of independent Tunisian women, published a number of articles over several years in a Tunisian weekly, one of which was titled «A Masters degree in women's studies at the University of Tunis: forming «professionals» in feminism»(Omrane). She began this article by pointing out how institutions in the future could «recruit qualified personnel rather than through on-thejob training or friends», while expressing some reservations concerning the Masters of Women's Studies program. She wrote that this program failed by having "serious lacks... no course on women's work, on women's health, on the 'invisible economy,' on the condition of rural women, etc». She viewed this program as having been developed in line with «the interests of those faculty calling for this program while excluding essential fields for training» and notes that the on-the-job training courses supposed to accompany this program «have not been planned nor perhaps even thought about». And finally, she referred to the lack of commitment of the teachers called upon to supervise the students.

Fatma Haddad-Chamakh, Professor of Philosophy and President of the specialized Masters in Women's Studies, as well as former member of the central committee of the UNFT from 1966-1972, member of the National Committee on Medical Ethics and later elected member of the board of the independent association AFTURD, responded to Nadia Omrane. She pointed 
out that the Masters provided a program in «women's studies» and not in «feminism.»

The most surprising part of this response is where Haddad-Chamakh questions Nadia Omrane regarding her «outside» status, asking on the basis of what «institutional, scientific, deontological authority» she speaks, to «play at denigrating and sapping the basis of a new and promising program in higher education?» This remark attempts to determine who is allowed to speak of what happens concerning a Masters in Women's Studies, excluding in this way any person who is not part of the committee or in-group: Nadia Omrane, outside this institution, has, according to the President of the Committee of the specialized Masters in Women's studies, no right to criticize or even make suggestions. Fatma Haddad-Chamakh concludes her response by condemning Nadia Omrane's contribution, claiming that her »criticism fails» («acte critique est manqué») and accusing her of «defamation» («énigrement»).

In rejecting critical discourse, the university representative is rejecting the ontological sources that are the foundation of creating such a masters program in the university, which is supposed to express a spirit of inquiry necessary to train the elites capable of responding to societal needs. And it is just because the university denied this reality that the Masters in Women's Studies was not renewed. How to explain this outcome? Fatma Haddad-Chamakh represented, for the authorities, a safety net, by specifying that the masters was in women's studies, not feminism, and that therefore this training would not create waves and call into question the existing order, institutions of power, patriarchy, economic power, etc. Fatma Haddad-Chamakh's move into retirement without the administration appointing her successor, raises questions as to the functions of the university. When Tunisian women philosophers were attacked in the press, neither the university nor the Ministry of Higher Education and Scientific Research came to their defense (Labidi 2015a forthcoming). And this exchange of press articles testifies to the tensions among the visions of different women's groups, as well as between women and the university/institutions of power. It has the advantage of showing us the culture that prevailed from 1956 to 2011 and the barriers between the women who were on the inside and those who were on the outside.

1.3.2. Among the other forms of exlusion from political institutions, Tunisia experienced the exclusion of women wearing the hijab from public institutions, established by Decree N 108 of $1981^{8}$. The hijab has been a focus

8. The Association Truth Action (l'Association Vérité Action) reports how even the bandana is banned from Tunisian schools(«l'Association Vérité Action, $58^{\text {ème }}$ anniversaire de la 
of political and cultural debate in Tunisia since the 1920s. F. Fanon wrote that French colonial opposition to the veil in Algeria was part of the effort to destroy the originality of a people. By excluding from public institutions women wearing the hijab, the Bourguiba and Ben Ali regimes did this in a manner that fit in well with Fanon's contention. Also, the World Organisation Against Torture noted in its 2002 report that more than 100 students wearing the hijab were excluded from schools, depriving them of an education; the case of 37 hijab-wearing girls in the administrative region of Bizerte not allowed to take their exams; women who had their hijab taken off by the police by force in the streets, etc. This harassment of women wearing the hijab upset many Tunisians as well as people in other Arab countries. And when in 2006 the television channel Al-Jazeera openly supported women wearing the hijab, the Tunisian government reacted by closing its embassy in Qatar. Ben Ali declared the hijab and the qamis (a long gown worn by men), as well as the beard for men, «of sectarian inspiration imported from abroad». Several ministers followed suit and argued that the hijab was «the symbol of a political adhesion hiding behind religion».

However, two court cases provided key turning points in this debate. In one, a complaint against the Minister of National Education and Training that the head of a school had abused power by excluding from courses a student wearing the Tunisian headscarf, was decided in favor of the plaintiff. In another case, the administrative tribunal judge Samia ElBikri put an end to the suspension of the teacher Saida Adali for wearing the hijab, stating that Circular N. 102 of 1986 was unconstitutional, and ordered that the teacher be reinstated in her position.

\section{Humor as a weapon of arab women cartoonists in the struggle opposing violence against women}

Among the consequences of the «Arab spring» we see the return of humorists in a major way throughout the region, with each working in his/her own way to reconstitute collective memory and break isolation and silence.

Humor, of course, varies according to historical and cultural contexts. Some artists were able to produce sarcastic works before the «Arab spring,» as the filmmaker Moncef Dhouib did. But this humor required a deep reading to understand how it was criticizing the Ben Ali regime while still managing to escape censorship (Lang). After the «Arab spring» some humorous television

Déclaration Universelle des Droits de l'Homme. Etat des droits de l'homme et des libertés en Tunisie: Prise de position»(Nawaat, 16 December 2006)). 
programs had great success without being able to completely escape censorship for not respecting «national symbols.» In another example of humor, supporters of Béji Caid Essebsi, in an effort to counter his critics who claimed his age of 89 years was an obstacle to his candidacy for president, put on Youtube a video segment supporting him, titled, My name is Sebsi, I'm sexy and I want the Korsi! (the chair, meaning the Presidential seat) (R.B.H). The lifting of censorship played an important role in the spread of humorous works.

Women contributed significantly to this situation of greater freedom. As soon as Ben Ali's fall was announced Tunisians discovered webcams by Sarah Ezzina, a Tunisian comedian based in France, where she imitated the wives of Arab heads of state such as Leila Ben Ali, Suzanne Mubarak, and Cheikha Moza (the First Lady of Qatar). With her humor distributed on Facebook, Sarah Ezzina became the first Tunisian woman humorist on the internet. Another Tunisian also emerged in this sector: Samia Orosemane, a Tunisian woman based in Europe who wears an African-style headscarf, is a comedian, laughs at herself and denounces, in her sketches, extremism and prejudices 9 . It is in this context, and using the same tools - the published press, online media, websites, Facebook, Youtube - that Arab women cartoonists produced and distributed their critical work.

The denunciation of violence and the reappearance of women's humor in public space following the «Arab spring» are signs foreshadowing the rediscovery of a freedom that had been lost since colonization and under the dictatorial regimes. I will be discussing here the political cartoons of four women cartoonists coming from the Maghreb, from the Mashreq, and from the Gulf countries, all of whom have made a strong impression in their own countries.

Women's associations are appealing to women cartoonists with increasing frequency for them to participate in campaigns to raise awareness of violence against women. For example, the Woman and Citizenship Association of El-Kef and the association Karama, among others, called upon Nadia Khiari, a teacher at the Institute of Fine Arts in Tunis and a cartoonist who emerged in January 2011, winning a number of prizes, to contribute cartoons to a campaign called, «You are highly respected and your rights are guaranteed $»$ («Kadrik Eali wa Hakik Madhmun»), in a situation where 55\% of Tunisian women victims of violence consider this to be something normal, with only $3.6 \%$ of victims bringing a complaint to the police and less than $2.5 \%$ going to a healthcare center (Benarous). Khiari, using the figure of a cat,

9. http://www.rts.ch/la-1ere/programmes/l-invite-du-12h30/6609774-samia-orosemanehumoriste-tunisienne-18-03-2015.html?f=player/popup, consulted on 18-07-2015. 
Willis, created on 13 January 2011, after Ben Ali's last speech and on the eve of his fleeing to Saudi Arabia, is able to say things in a humorous or sarcastic way, downplaying the drama.

2.1. Lilia Halloul, of the same generation as Nadia Khiari, was for a long time the only woman cartoonist in Tunisia, until the outbreak of the «Arab spring.» Censorship under the regimes of Habib Bourguiba and Ben Ali prevented many cartoonists from practicing their art, and certainly from earning a living at it. Halloul worked for a number of years as an illustrator for a children's magazine, up until January 2011 when her career took a new turn.

She belongs to a group of Tunisian cartoonists - all of the others are men with whom she joins in exhibits, workshops, and cartoon festivals organized in the interior regions of the country to spread knowledge of this art form and to introduce it to children. Her work addresses socio-political and gender issues, the texts of her cartoons are in Arabic, and her work is distributed via online media and social networks. In 2014 her work began to treat women political figures and the Tunisian presidents - the latter had been forbidden in the past. Among the woman political figures she portrayed was Meherzia Labidi [no relation to the author], vice-president of the ANC (Assemblee nationale constituante, which was the Tunisian parliament from 2011 to 2014), Minister of Tourism Amel Karboul; and Kalthoum Kennou, presidential candidate in 2014. In addition, she herself became a candidate - unsuccessful - for parliament on an independent election list, for the October 2014 elections, to represent the region of Ben Arous (Labidi 2015b (forthcoming)).

Shocked when Habib Ellouze (a Nahdha party member of the ANC who earlier had been exiled to Algeria under Bourguiba's rule) stated that «the khitan (excision) of girls is an esthetic operation» («le khitan des filles (excision) était une opération esthétique»), Lilia Halloul produced a cartoon denoucing the violence that some Nahdha party members wished to inflict on young girls. Ellouze's declaration was uttered in a context where the Nahdha party had been victorious in the October 2011 elections and a number of preachers had arrived from the Mashreq to give lectures on themes that were foreign to Tunisian culture, such as the khitan for girls, the hijab for young girls in nursery schools, customary marriage (orfi marriage, where the marriage is not legally registered), etc.

Lilia Halloul's cartoon shows a vertical pair of open scissors, the handle resting on a platform on which is written Khitan alBanat (Excision of girls). One of the scissors' blades has the shape of a witch's long-nailed hand and is grabbing the girl by one of her legs while she is suspended in mid-air and 


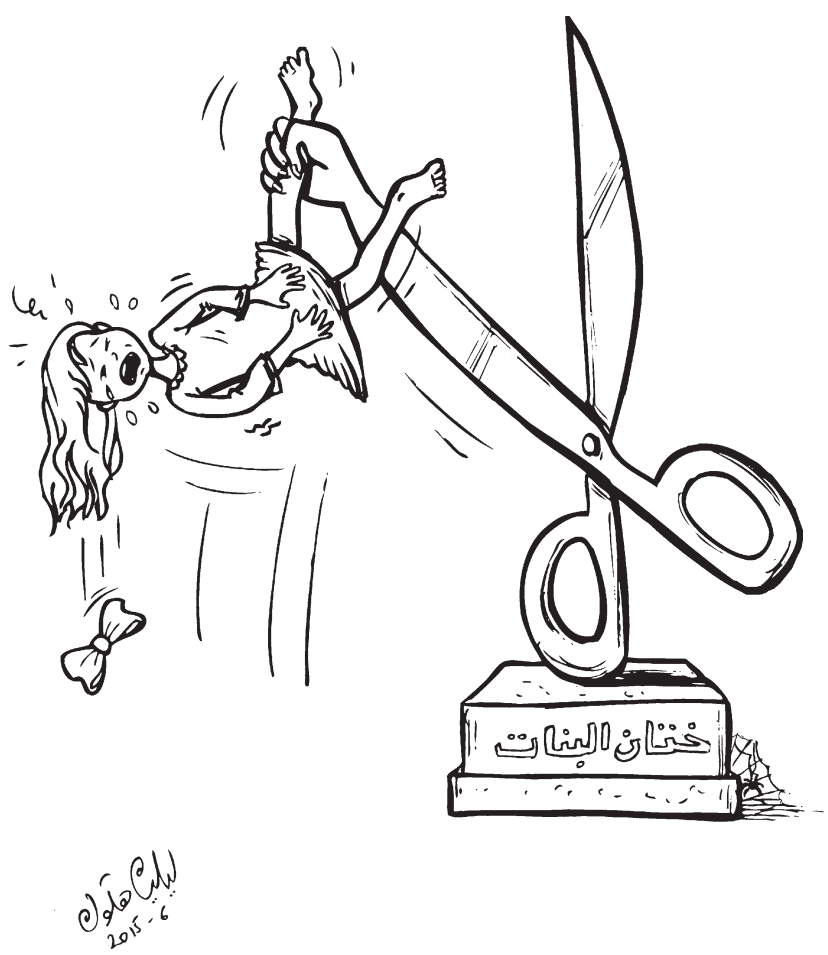

crying. The girl's hands are placed on her skirt so as to stop anyone from touching her genital area. The ribbon that had been holding her hair is falling to the ground, presaging the fall into horror that young girls will face if the country's women, its national organizations, and the political parties, do not fight against excision. The governing body of the corporation of doctors condemned the khitan, warning doctors against any deviation and reminding them that they were obliged to denounce such practices or face the penalty of being accused of complicity and risking expulsion and being forbidden to practice their profession.

The khitan of girls, among a number of other issues concerning women, pushed the Troika, under popular pressure, to leave power once the Constitution had been adopted in January 2014 - a constitution that was not based on Sharia and that recognized women's rights. The Troika was replaced by a government of technocrats charged with preparing the October 2014 elections.

2.2. The Egyptian cartoonist Doaa El-Adl, like Lilia Halloul for a long time the only woman cartoonist in her country, worked in Egypt that had greater 
freedom of press than Tunisia and was able to contribute to several independent newspapers, such as Al-Destour, Rose Al-Youssef Magazine and Al-Masry Al-Youm, in addition to producing illustrations for children's magazines and for human rights organizations. She has won a number of prizes, such as the Award of Journalistic Distinction (the first woman to receive this award, in 2009); the 41st Forte dei Marmi Prize for Political Satire in 2013; the International Award for Press Cartoonists in Geneva in 2014; and an Egyptian award given by the Journalists' Syndicate.

El-Adl says, «What I criticize are some of the habits that I think are wrong and there are many and they must be totally reconsidered! For example, circumcision»(Clitoraid). The khitan of girls is a form of violence against which Egyptian feminist movements have been struggling for years. In 2010, 50.3\% of Egyptian girls between the ages of 15 and 19 had undergone this operation, compared to 97\% in 2003 (Attiya). In February 2013 El-Adl produced a cartoon showing a man on a ladder climbing up between a woman's legs, holding a scissors and preparing to cut a red flower placed at the woman's genital area (http://www.clitoraid.org/news.php?extend.129.4).

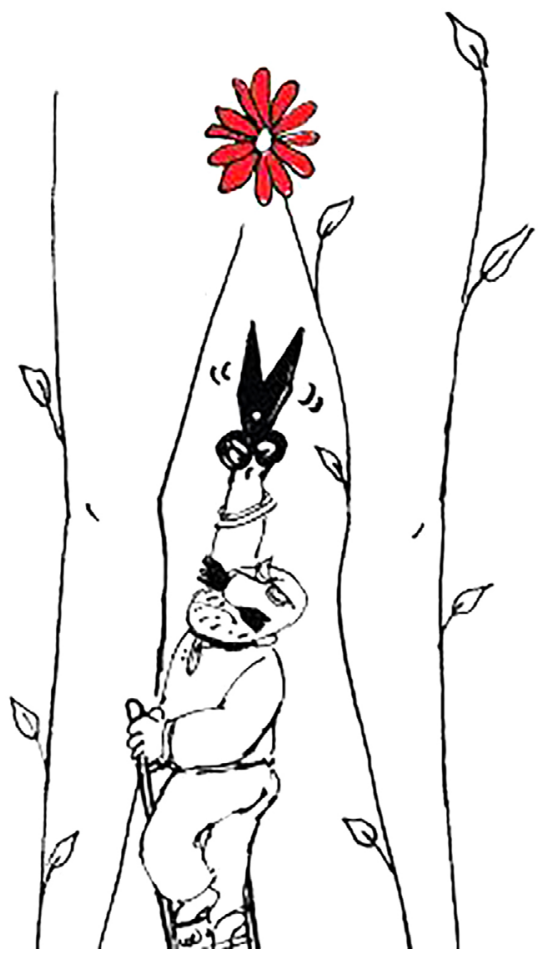

Feminismo/s 26, diciembre 2015, pp. 145-174 
She has felt compelled since the Egyptian events of the «Arab spring,» «to draw cartoons about women in order to defend her own existence, her personal freedom that are threatened under the rule of the Muslim Brotherhood» (Benjamin). She specifies that

I draw cartoons not only about FGM but also other problems relating to Egyptian women like domestic violence, marrying minors, [sexual] harassment, violence against women, and even a new phenomenon in Egyptian society called "sexual mass terror,» a condescending way to refer to female demonstrators. I just cannot remain silent about all of these issues (Clitoraid).

Two cartoons illustrate this artist's commitment to defend the rights of women and girls. One cartoon criticizes the mistreatment of young girls given in marriage to rich men from the Gulf countries, a treatment that amounts to both psychological and economic violence, a theme we will see later in the work of the Bahraini cartoonist Sara Qaed.

Here, Doaa El-Adl shows a rich, corpulent older man with a large mustache and dressed in the manner of men from the Gulf, happily pushing a shopping cart that carries the four young girls he has bought, each of them wearing a wedding dress and displaying the sales ticket attached to their headdress. The girls display, variously, expressions of anger, pain, and unhappiness. The artist is here denouncing a practice seen not only in rural areas of Egypt but also in poorer urban sections of Cairo.

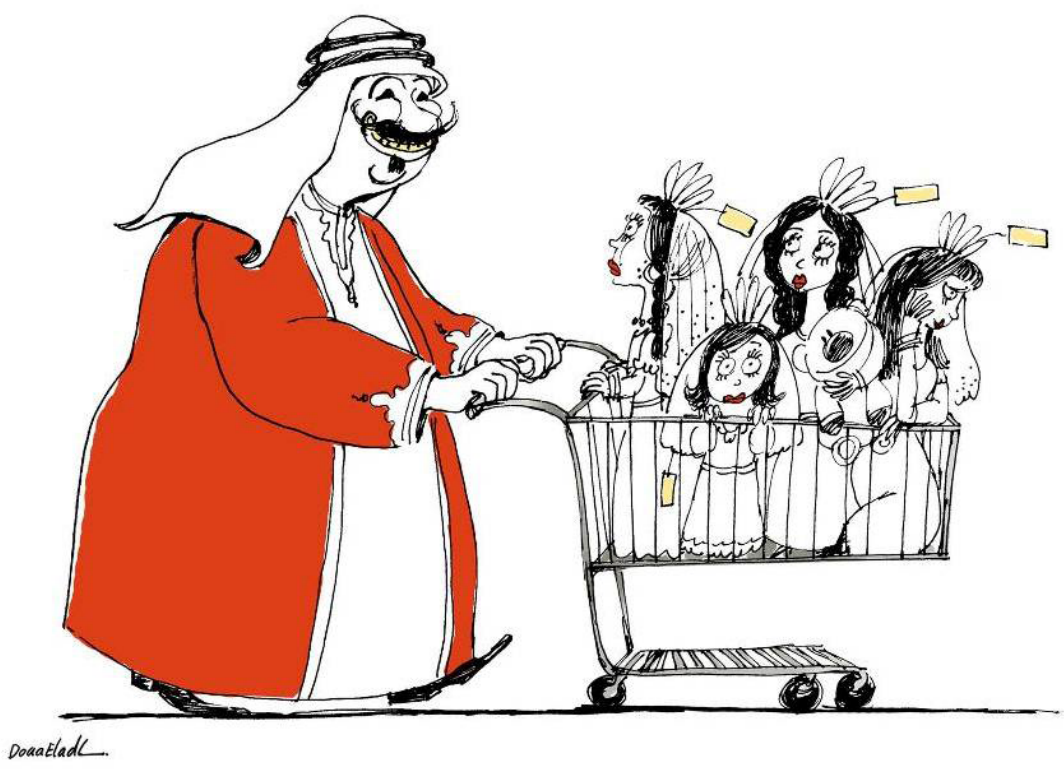

Feminismo/s 26, diciembre 2015, pp. 145-174 
Another of Doaa El-Adl's cartoons presents a view of political violence, symbolized here by a disproportion in the space occuped by the figures, commenting on their different political power in society.

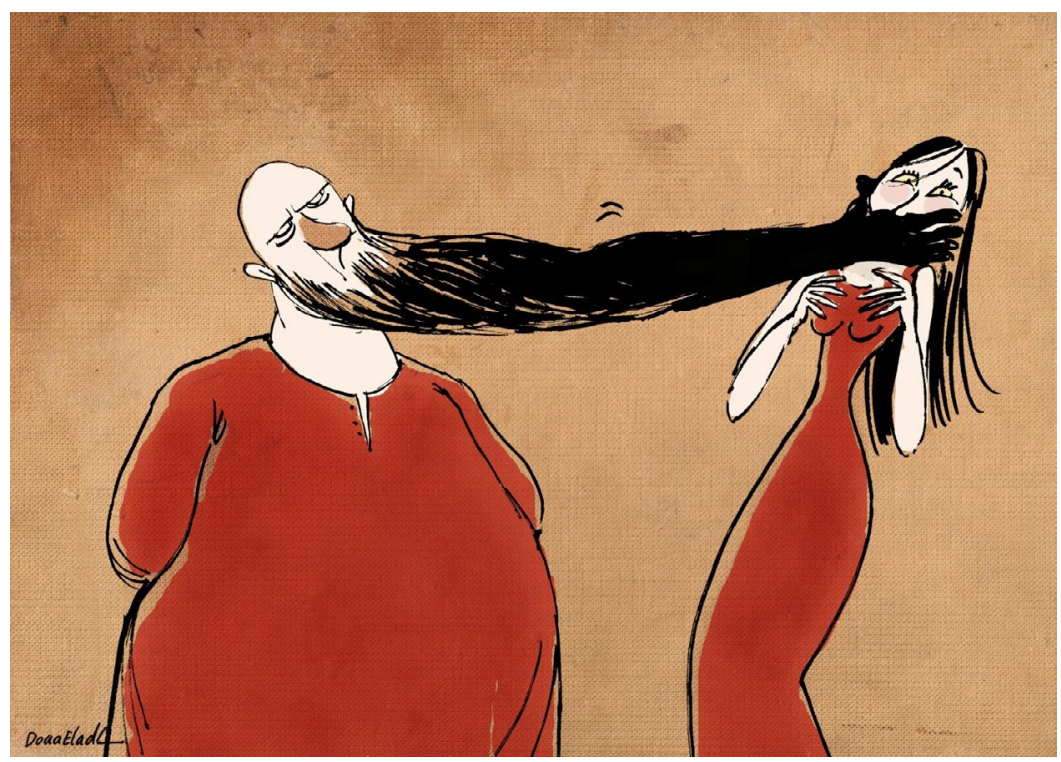

Here, the beard of the Salafist is transformed into an arm that blocks the woman's mouth, stifling her speech. This cartoon was inspired, the cartoonist says, by a real event where, during a meeting, a man stopped Shahinda Mekled, a woman peasant activist for land reform in Egypt from 1952 to 1966, from speaking, thus showing he did not recognize that a woman's voice could express the revolution. The beard for Doaa El-Adl, like the Salafist's vertical pair of open scissors in the Tunisian Lilia Halloul's cartoon, has become a virtual arm that constitutes a danger for women.

For her critique Doaa El-Adl has paid a price: in 2013 she became the first cartoonist in Egypt to face blasphemy charges for insulting a prophet, Adam, in a cartoon published by the newspaper, Al Masry Al Youm.

2.3. Another woman cartoonist, Sara Qaed of Bahrain, has addressed the issue of children's rights, which are at the center of interests of women in the Arab world. As in Tunisia, where feminists brought a legal case against Bahri Jlassi, head of the political party Opening and Faithfulness, for having proposed early marriage as a solution for youth celibacy, the Bahraini political cartoonist Sara Qaed has also criticized early marriage. Qaed, who contributed to the 
newspaper Al-Arabi al-Jadid and, like a number of women cartoonists, works also as an illustrator for children's stories, has held exhibits of paintings and cartoons at the Bahrain National Museum as well as abroad, at the Stripdagen Haarlem Festival in Holland, and in Gaza, Palestine (Qaed).

In May 2015 Sara Qaed put on her Facebook page a cartoon that criticizes girls' early marriage. Here she portrays an old man with a mustache, with just a few hairs on his head and with his cane in front of him, seated on a sofa next to a young girl with a timid face who is wearing a wedding dress with a veil on her head. The disproportion of the two bodies, with the large old man occupying much of the couch and the much smaller girl holding a bouquet of flowers in one hand and gripping the old man's arm with the other, accentuates their difference in age. Two arms reach into the picture from either side of the couch: one, with «ignorance» written on the forearm, is directed toward the old man and holds a perfume vaporizer emitting the smoke of incense; the other, with the word «poverty,» extends toward the young bride and holds a perfume sprinkler $(\text { mrach })^{10}$.

This cartoon denounces early marriage for girls in Bahrain, where the legal marriage age for girls is 15 for both Shi'a and Sunni. In this cartoon Sara Qaed sees the marriage as a transaction between a rich man and a poor young girl. In 2004, 8\% of girls in Saudi Arabia between the ages of 15 and 19 were married, 6.1\% in 2005 in the United Arab Emirates, 4.6\% in 2010 in Bahrain, 4\% in 2005 in Kuwait, and 3.4\% in 2004 in Qatar (De Bel-Air).

2.4. Economic violence concerns a large majority of women living in the Arab world, and this includes women university graduates, who often face unemployment. Hana Hajjar, the only woman cartoonist in Saudi Arabia, works for an English-language Saudi newspaper, whose readers are mostly foreigners or upper middle-class Saudis, and denounces this situation in several of her cartoons. ${ }^{11}$ Her women readers admit that they recognize themselves in her cartoons, something that gives her great satisfaction because she can express what other women cannot say in words and she is pleased to encourage them to reflect on their condition. She belongs to a generation that hopes to encourage change through the use of humor. When in 2013 Saudi women put videos on social networks showing themselves driving cars, the 28 year-old Saudi

10. https://www.facebook.com/372077007816/photos/a.372091017816.154250. $372077007816 / 10152951414992817 /$ ?type $=1 \&$ theater

11. Saad Al-Dosari writes that Saudis, in the face of humor, tend «to close our eyes when it comes to our paradoxes, we do not like to bring them to the light of discussions and change. That is why making fun of them hurts and usually strikes a chord with us. We are very sensitive to criticism, let alone jokes!» (Al-Dosari). 
actor Hisham Fageeh parodied Bob Marley's famous «No woman no cry» with «No woman no drive,» showing his solidarity with the women drivers. Posted on Youtube, this was seen by 7.3 million viewers in less than a week and Hajjar produced her own cartoon on this subject ${ }^{12}$.

Her cartoons challenge gender roles, inequality between the sexes, and political policies existing in a context that is hostile to women. In a CNN interview she stated, «They've [men] put women in an oppressive situation ...I feel it is my duty towards women to speak out on their behalf, because I have the tools and venue to do so... I like to see how much I can push people to think, but I am mindful never to cross societal red lines» (Sterns). Hana Hajjar uses her cartoons to criticize the way power hides behind an aggressive interpretation of religion, limiting women's capacity to fulfill themselves. She expresses this explosive situation in her cartoons, in one of which we see a woman standing with a bomb under her abaya, with a man's hand extending into the picture and ready to light the fuse emerging from her abaya, while eight other hands, of men, each holds a magnifying lens up to her body ${ }^{13}$.

Educating girls is a sector in which there has been great progress in recent years in the Gulf countries: more than $50 \%$ of university students are women and they perform better than the men students do. Yet employment for women is extremely rare, which is being increasingly seen by the women themselves as institutional violence against them. Three of Hanna Hajar's cartoons illustrate this tension in a country where the labor law of 2006 states that women can only work in fields suited to their nature. One shows women in great numbers, with a large city in the background, holding their CVs and looking up at a large faucet, on which is written «Jobs», and from which trickles a few drops, indicating the scarcity of employment for women ${ }^{14}$.

Another cartoon titled, "Jobs in the public sector,» shows a man and a woman, each holding a file to support their job application, seated on either side of a balance scale, with the weight of the man pulling his side down. Meanwhile, a hand extends toward the man, apparently accepting his file while the woman remains without a job. The cartoonist here is criticizing the

12. https://www.google.tn/search?q=hana+hajjar\&biw=1024\&bih=671\&source=lnms\& tbm=isch\&sa=X\&ved=0CAYQ_AUoAWoVChMI-puiObaSxwIVS7UUCh3JswIx\#imgrc $=$ ilN666Y-eq0tKM\%3A

13. https://www.google.tn/search?q=hana+hajjar\&biw=1024\&bih=671\&source=lnms\& tbm $=$ isch\&sa=X\&ved=0CAYQ_AUoAWoVChMI-puiObaSxwIVS7UUCh3JswIx \#imgrc=RS2XIBcqFyvTDM\%3A

14. https://www.google.tn/search? q=hana+hajjar\&biw=1024\&bih=671\&source= lnms\&tbm=isch\&sa=X\&ei=1HiQVaC3HYXiUaaXgPgI\&ved=0CAYQ_AUoAQ \& $\mathrm{dpr}=1 \#$ imgrc $=$ sG-gnMzwEt3P3M\%3A. 
state which, applying restrictions to employment in the public sector, continues to favor men ${ }^{15}$.

Aware that such a situation sharpens competition among women, Hanna Hajjar has produced a cartoon that opposes two different sorts of women: one, quite corpulent, with large glasses and wearing an intellectual-style hijab that reaches to her waist over a long skirt, has her candidacy rejected despite a voluminous $\mathrm{CV}$; the second woman is slim, heavily made-up, and wears a slight hijab and a tight long dress that highlights the shape of her body, gets the job despite the flimsy CV she is holding in her hand ${ }^{16}$.

The cartoons shown here deal with the hurdles faced by women seeking work. Unemployment of both sexes aged between 20 and 24 reaches $40 \%$, and $70 \%$ for women, and the government is attempting to remove illegal foreign workers and replace them with Saudi citizens (Beaugrand). Some positive steps have been taken but these haven't had a significant impact on the situation of unemployed women. The rate of participation in the employed population of women aged 15 and older was 20\% in 2013 in Saudi Arabia, 39\% in Bahrain, 24\% in Egypt, and 25\% in Tunisia (World Bank).

\section{Conclusion}

The cases of violence against women that we have looked at here help us to understand the variety and complexity of this violence. The context of the «Arab spring» and the lifting of censorship in Tunisia since 14 January 2011 has made possible a discussion of violence against women that had not been possible before.

However, the unwillingness of the 2014 Carthage Festival to select the film Al-Siraa, a parliamentary and judicial system which wavers in its recognition of victims' rights, the difficulties encountered by the IVD in gathering testimony from women who had been victims of violence when arrested and/ or interrogated, the challenge to the very existence of the IVD by certain parties - all reinforce the views of those who do not recognize, in Max Weber's terms, the legitimacy of the state to monopolize violence. In addition, when some state institutions like the presidency attempt to limit the IVD's role and

15. https://www.google.tn/search?q=hana+hajjar\&biw=1024\&bih=671\&source=lnms\& tbm $=$ isch\&sa=X\&ved=0CAYQ_AUoAWoVChMI-pui0baSxwIVS7UUCh3JswIx \#imgrc $=49$ y 8 bIfQPI $717 \mathrm{M} \% 3 \mathrm{~A}$.

16. https://www.google.tn/search?q=hana+hajjar\&biw $=1024 \& b i h=671 \&$ source $=\operatorname{lnm} s \&$ tbm=isch\&sa=X\&ved=0CAYQ_AUoAWoVChMI-puiObaSxwIVS7UUCh3JswIx \#imgrc=19j8Uq9J0ZsUWM\%3A0. 
the construction of historical memory, this can only encourage the emergence of a murderous utopianism.

If it seems obvious to Tunisian women today that their lack of access to political and decision-making positions constitutes a form of institutional violence against which they must struggle and work to increase public awareness, it seems less easy to recognize institutional violence when it is directed against rural women who have been the victims of coercive development policies. These coercive policies appear today increasingly as a form of control over marginal groups that endangers their social rights.

The symbolic violence that occurs when, according to Pierre Bourdieu, power extracts submissions which are not perceived as such, helps us understand why and how a program of women's studies is put in opposition to one in feminist studies and is then offered by a state which promotes, as a norm, the exclusion of women wearing the hijab from public institutions, turning them into parias.

While some forms of institutional and symbolic violence have been denounced, others haven't. Because as feminists, we too are victims of authoritarian/dictatorship discourses that structure and distort the psyche of a society and its elite, suffering as we do from aspects of this discourse that I call the 4 I-s: Influence, Intimidation, Insult, and Infamy (where it is seen as a result of defamation). As we see in today's Tunisia, the generation that grew up under the Ben Ali regime sees itself as dominated by three traits - authoritarianism, individualism (everybody for him/herself), and being entitled. As for being socially committed to action, this is not seen as of high value. We rejoin here Janine Puget when she says that, in these contexts, the subject who needs to create such defensive barriers is denying the terror that society exercises. And it is important for today's feminists to admit that we too have been affected by state, institutional, and symbolic violence, that no one has been able to escape it, and that admitting this can help us in understanding and being effective in our struggles.

Can the women cartoonists such as those we have discussed above help their societies restore a memory that gives meaning to the suffering experienced by preceding generations? I suggest that humor, in situations where a legalistic discourse has failed, can help to denounce the violence done to women, so that succeeding generations will neither live through it again nor reproduce it. But, at the same time, we have seen how neither feminist discourse, nor the cartoonists' cartoons, take into account the reality of marginalized and excluded women, testifying to the urgency of reinventing feminism in the Arab world, so that it can articulate and help solve the problems of all women in these societies. 


\section{Bibliography}

ABDELATIF, Ibtihel. «Ibtihel Abdelatif, Présidente de la commission femmes à l'IVD». Interviewed by Thierry Bresillon. < https://inkyfada.com/2015/07/ ibtihel-abdelatif-commission-femme-ivd-tunisie/>, consulted on 10-07-2015.

ALBÓ, Xavier and Raul Barrios. Violencias encubiertas en Bolivia. La Paz: CIPCA/ ARUWIYIRI, 1993.

AL-DOSARI, Saad. «Saudis' psychology of humor». Arab News, 14 January 2013. <http://www.arabnews.com/columns/saudis\%E2\%80\%99-psychology-humor $>$, consulted on 13-07-2015.

AttiYA, Manar. «Egypte: l'excision en chute libre, enfin». Al-Ahram Hebdo(Cairo), 13 November 2013.

BANGRÉ, Habibou. «La Tunisie déclare la guerre au voile»(05-07-2015). <http:// www.afrik.com/article10549.html>, consulted on 05-07-2015.

BEAUGRAND, Claire. «La réforme du marché du travail en Arabie Saoudite». Orient 21 (13 November 2013). http://orientxxi.info/magazine/reforme-du-marchedu-travail-en,0304, consulted on 17-07-2015

BENAROUS, Rym. «Femmes violentées: il n'y a plus de raison de se confiner dans le silence !» Le Temps (Tunis), 1 May 2015.

Ben BrAhim, Y., F. Halouani, A.Falfoul. «Projet de partenariat DSSB-UNICEFATSR Réduction de la mortalité maternelle en Tunisie Mission d'étude préliminaire de la région de Kasserine.» <http://www.onfp.tn/mm/index_htm_files/ youssefbb.pdf $>$, consulted on 19-07-2015.

Benjamin, Medea. «Egyptian female cartoonist pokes fun at fundamentalists»(29-03-2013). < http://www.counterpunch.org/2013/03/29/egyptian-female-cartoonist-pokes-fun-at-fundamentalists/>, consulted on 21-07-2015.

Ben Mohamed, Meriem (pseudonym). Coupable d'avoir été violée. Paris: Michel Lafon, 2013.

Ben Romdhane, Habiba. «Enquête sur la mortalité maternelle en Tunisie, 20092010. Office National de la Famille et de la Population (24/11/2011)». <PowerPoint - ONFP>, consulted on 13-07-2015.

Bourdieu, Pierre. Raisons pratiques. Sur la théorie de l'action. Paris: Seuil, 1994.

Clitoraid. «Egyptian woman cartoonist, Doaa ElAdl, publishes a controversial cartoon on FGM - She tells clitoraid why». ClitoraidNews, 4 March 2013. <http:// www.clitoraid.org/news.php? extend.129.4>, consulted on 22-07-2015.

DE BEL-AIR, Françoise. «Mariage et famille dans le golfe Arabe: vers un bouleversement politique?» Espace, Populations, Sociétés («Changement démographique et changement social dans les Etats du Golfe Arabo-persique») 2012.2: 79-96. 
Egalité Maintenant. «Bosnie-Herzegovine: viols collectifs, grossesses forcées, génocide. 1 June 1993». <http://www.equalitynow.org/fr/take_action/bosnie_ herz_govine_action32>, consulted on 10-07-2015.

FANON, Frantz. Sociologie d'une révolution. (L'an $V$ de la révolution algérienne). Paris: François Maspero, 1972.

HADDAD-CHAMAKH, Fatma. «A propos de l'article intitulé 'Former des «professionnelles» du féminisme'». Réalités 946(12/18-02-2004): 14.

Halimi, Gisèle. Le récit de Djamila Boupacha. (Preface by Simone de Beauvoir). Paris: Gallimard, 1962.

Inter-Parliamentary Union. «Les femmes dans les parlements nationaux»(01-06-2015). <www.ipu.org/wmn-f/classif.htm>, consulted on 25-07-2015.

KAËS, René. «Ruptures catastrophiques et travail de la mémoire: notes pour une recherche». Violence d'Etat et psychanalyse. Eds. Janine Puget and René Kaës. Paris: Dunod, 1989: 169-204.

LABIDI, Lilia. Qamus as-siyar li-lmunadhilaat at-tunisiyaat, 1881-1956 [Biographical Dictionary of Tunisian Women Militants]. Tunis: Imprimerie Tunis Carthage, 2009.

LABIDI, Lilia. «Tunisia: Policies and Practices for Promoting Social Justice for Rural Women during a Democratic Transition». Is the Arab Awakening Marginalizing Women? Ed. Haleh Esfandiari. Washington DC: Woodrown Wilson International Center for Scholars, 2012: 23-27. <http://www.wilsoncenter. org/sites/default/files/Arab\%20Awakening\%20Marginalizing\%20Women_0. pdf>

LABIDI, Lilia. «Historic Women Figures and Women's Daily Struggles in Tunisia: neglect and societal responsibility». Minorites, Women, and the State in North Africa. Ed. Moha Ennaji. New Jersey: Red Sea Press, 2015: 121-149.

LABIDI, Lilia. «Cartoonist Lilia Halloul: Gender and the democratic transition in Tunisia». Journal of Middle East Women's Studies 11.3 (November 2015): 354-358.

LANG, Robert. «Strategies of subversion in Ben Ali’s Tunisia: Allegory and Satire in Moncef Dhouib's 'The TV is coming'». Humor in Middle Eastern Cinema. Eds. Gayatri Devi and Najat Rahman. Detroit MI: Wayne State University Press, 2004: 56-78.

M.B.Z. «Le gouverneur de Kasserine réquisitionne 6 médecins gynécologues du secteur privé» (04-08-2015). <http://www.businessnews.com.tn/Legouverneur-de-Kasserine-r\%C3\%A9quisitionne-6-m\%C3\%A9decinsgyn\%C3\%A9cologues-du-secteur-priv\%C3\%A9,520,57969,3>, consulted on 19-07-2015.

Omrane, Nadia. «Un master d'études féminines à l'université de Tunis. Former des 'professionnelles' du féminisme». Réalités 943(22/28-01-2004): 18. 
Programme de Communication sur le Genocide au Rwanda et les Nations Unies. «La violence sexuelle: un outil de guerre.» (March 2014). <http://www. un.org/fr/preventgenocide/rwanda/about/bgsexualviolence.shtml>, consulted on 11-07-2015.

PugET, Janine. «Etat de menace et psychanalyse. De l'étrange structurant à l'étrange aliénant». Violence d'Etat et psychanalyse. Eds. Janine Puget and René Kaës. Paris: Dunod, 1989: 1-40.

QAED, Sara. «In the name of god - Sara Qaed» (07-03-2015). Video presented by Universal Tolerance Organization. <http://universaltolerance.org/en/archive/ item/1246-in-the-name-of-god-sara-qaed>, consulted on 22-07-2015.

R.B.H. «Le tube de l'année: My name is Sebsi, I'm sexy and I want the Korsi!»(1710-2014). <http://www.businessnews.com.tn/le-tube-de-lannee-my-name-issebsi-im-sexy-and-i-want-the-korsi-,534,50308,3>

RICON, Lia. «L'autoritarisme dans la société argentine et son rôle dans l'apparition de pathologies graves». Violence d'Etat et psychanalyse. Eds. Janine Puget and René Kaës. Paris: Dunod, 1989: 67-85.

SAHLI, Sadok J. Sociétés et procréation. Tunis: Publications de la Faculté des Sciences Humaines et Sociales, 1992.

SALmonA, Muriel. «Violences sexuelles». < http://www.memoiretraumatique.org/ memoire-traumatique-et-violences/violences-sexuelles.html>, consulted on 27-07-2015.

Santé-tn. «L'excision chez les filles: le président du collège tunisien d'urologie, Dr Riadh Ben Slama nous parle»(27-02-2012). Interview conducted by E.K.L. < http://www.babnet.net/festivaldetail-46312.asp>, consulted on 12-07-2015.

SASSON, Jean P. The rape of Kuwait: The true story of Iraqi atrocities against a civilian population. Knightsbridge Pub Co Mass, 1991.

STERNS, Olivia. «Female cartoonist's provocative work challenges Saudi society». http://edition.cnn.com/2009/WORLD/meast/10/27/hajjar.female.cartoonist/ index.html?iref=24hours, consulted on 13-07-2015.

TouAti, S., A. Ben Abdelaziz, A. Mtiraoui, and M. Marzouki. «La prévalence contraceptive dans une zone périurbaine de la ville de Sousse». Eastern Mediterranean Health Journal 7.6 (November 2001): 943-955.

UlRIKSEN VIGNAR, Maren. «La transmission de l'horreur». Violence d'Etat et psychanalyse. Eds. Janine Puget and René Kaës. Paris: Dunod, 1989: 122-150.

VAllin, Jacques and Zamia Ouadah-Bedidi. «Maghreb: la chute irrésistible de la fécondité». Population et Sociétés 359 (July-August 2000): 1-4

World Bank. «Labor force participation rate». < http://data.worldbank.org/indicator/SL.TLF.CACT.ZS>, consulted on 12-07-2015. 